\title{
Orbital forcing of organic carbon burial in the proto-North Atlantic during oceanic anoxic event 2
}

\author{
Marcel M.M. Kuypers ${ }^{\mathrm{a}, \mathrm{c}, *}$, Lucas J. Lourens ${ }^{\mathrm{b}}$, W. Irene C. Rijpstra ${ }^{\mathrm{a}}$, \\ Richard D. Pancost ${ }^{\mathrm{a}, 1}$, Ivar A. Nijenhuis ${ }^{\mathrm{b}, 2}$, Jaap S. Sinninghe Damsté ${ }^{\mathrm{a}, \mathrm{b}}$ \\ ${ }^{a}$ Netherlands Institute for Sea Research (NIOZ), Department of Marine Biogeochemistry and Toxicology, P.O. Box 59, \\ 1790 AB Den Burg, The Netherlands \\ ${ }^{\mathrm{b}}$ Faculty of Geosciences, Department of Earth Sciences, Utrecht University, Budapestlaan 4, 3584 CD Utrecht, The Netherlands \\ ${ }^{c}$ Max Planck Institute for Marine Microbiology, Celsiusstrasse 1, 28359 Bremen, Germany
}

Received 13 May 2004; received in revised form 27 September 2004; accepted 29 September 2004

Available online 2 November 2004

Editor: E. Bard

\begin{abstract}
The Cenomanian/Turonian (C/T) intervals at DSDP Sites 105 and 603B from the northern part of the proto-North Atlantic show high amplitude, short-term cyclic variations in total organic carbon (TOC) content. The more pronounced changes in TOC are also reflected by changes in lithology from green claystones $(\mathrm{TOC}<1 \%$ ) to black claystones (TOC $>1 \%)$. Although their depositional history was different, the individual TOC cycles at Sites 105 and 603B can be correlated using stable carbon isotope stratigraphy. Sedimentation rates obtained from the isotope stratigraphy and spectral analyses indicate that these cycles were predominately precession controlled. The coinciding variations in $\mathrm{HI}, \mathrm{OI}, \delta^{13} \mathrm{C}_{\mathrm{org}}$ and the abundance of marine relative to terrestrial biomarkers, as well as the low abundance of lignin pyrolysis products generated from the kerogen of the black claystones, indicate that these cyclic variations reflect changes in the contribution of marine organic matter (OM). The cooccurrence of lamination, enrichment of redox-sensitive trace metals and presence of molecular fossils of pigments from green sulfur bacteria indicate that the northern proto-North Atlantic Ocean water column was periodically euxinic from the bottom to at least the base of the photic zone $(<150 \mathrm{~m})$ during the deposition of the black claystones. In contrast, the green claystones are bioturbated, are enriched in $\mathrm{Mn}$, do not show enrichments in redox-sensitive trace metals and show biomarker distributions indicative of long oxygen exposure times, indicating more oxic water conditions. At the same time, there is evidence (e.g., abundance of biogenic silica and significant ${ }^{13} \mathrm{C}$-enrichment for $\mathrm{OC}$ of phytoplanktic origin) for enhanced primary productivity during the deposition of the black claystones. We propose that increased primary productivity periodically overwhelmed the oxic OM remineralisation potential of the bottom waters resulting in the deposition of OM-rich black
\end{abstract}

* Corresponding author. Tel.: +49 421 2028634; fax: +49 4212028690.

E-mail address: mkuypers@mpi-bremen.de (M.M.M. Kuypers).

${ }^{1}$ Current address: Organic Geochemistry Unit, Bristol Biogeochemistry Centre, School of Chemistry, University of Bristol, Cantock's Close, Bristol BS8 1TS, United Kingdom.

${ }^{2}$ Current address: Shell SEPTAR, EPT-AGI, Rijswijk, The Netherlands. 
claystones. Because the amount of oxygen used for OM remineralisation exceeded the amount supplied by diffusion and deepwater circulation, the northern proto-North Atlantic became euxinic during these periods. Both Sites 105 and $603 \mathrm{~B}$ show trends of continually increasing TOC contents and HI values of the black claystones up section, which most likely resulted from both enhanced preservation due to increased anoxia and increased production of marine OM during oceanic anoxic event 2 (OAE2). (C) 2004 Elsevier B.V. All rights reserved.

Keywords: Cretaceous; Cenomanian; Turonian; oceanic anoxic event; OAE2; black shales; paleoceanography; orbital forcing; biomarkers; trace metals; photic zone anoxia; organic carbon burial

\section{Introduction}

During the Cenomanian/Turonian $(\mathrm{C} / \mathrm{T})$ transition, laminated sediments rich $(>1 \%)$ in organic carbon (OC; black shales) were globally deposited in a variety of paleobathymetric settings [1]. Evidence for the global nature of this organic carbon burial event is provided by a coinciding increase in ${ }^{13} \mathrm{C} /{ }^{12} \mathrm{C}$ ratios for marine carbonates and organic matter. This positive excursion in $\delta^{13} \mathrm{C}$ values likely resulted from preferential removal of ${ }^{12} \mathrm{C}$ by the enhanced burial of ${ }^{13} \mathrm{C}$-depleted $\mathrm{OC}$ as a response to the so-called 'oceanic anoxic event (OAE) 2' [2]. The widespread deposition of black shales during the OAE2 has been attributed to either decreased $\mathrm{OM}$ remineralisation resulting from a decreased oxygen flux (preservation model) [3] or increased primary productivity overwhelming the oxic OM remineralisation potential of the water column (productivity model) [1]. The preservation model has mainly been applied for tectonically isolated basins, such as the Cretaceous North and South Atlantic [4,5]. Model simulations for the Albian and early Cenomanian ocean circulation [6] [Bice, personal communication] show that especially the proto-North Atlantic was prone to water column anoxia due to a combination of overall sluggish circulation (possibly halothermal instead of thermohaline), high sea surface temperatures and the tectonically isolated nature of the proto-North Atlantic basin (Fig. 1).

The recurrence of thinly laminated OM-rich sediments devoid of traces of benthic activity indicates that proto-North Atlantic bottom waters were indeed periodically anoxic during the mid-Cretaceous $[3,7]$. Sedimentary derivatives (isorenieratane) of a pigment (isorenieratene) indicative of anoxygenic photosynthetic bacteria recovered from abyssal and shelf sites indicate that anoxic conditions extended even into the photic zone of the southern proto-North Atlantic during the OAE2 [8]. Recently, we provided evidence (e.g., occurrence of molecular fossils of green sulfur bacteria, lack of bioturbation and high abundance of redox sensitive trace metals) that the southern part of the proto-North Atlantic Ocean was already euxinic up into the photic zone well before the OAE2 [9]. Sedimentological and geochemical data from the proto-North Atlantic indicates that anoxic bottom water conditions persisted in the southern and southeastern part during most of the late Aptian to late Cenomanian [10]. However, in the northwestern part, conditions were more versatile with alternating oxic and anoxic periods [10]. Herbin et al. [11] showed that the OAE2 interval at DSDP Sites 105 and 603B is not a single homogeneous black shale layer but rather a condensation of several OC-rich black claystone layers alternating with thinner levels of OC-poor green claystone. The coexistence of permanently anoxic conditions in the southern part and alternating oxic and anoxic conditions in the northwestern part of the proto-North Atlantic has been attributed to restricted deep water exchange as a result of a barrier between the southeastern and northwestern part of the basin [10]. The repeated deposition of OC-rich black shales in the northwestern proto-North Atlantic during OAE2 is reminiscent of the sapropel deposition in the Mediterranean during the Plio-Pleistocene [12] and Coniacian-Santonian black shale deposition in the eastern tropical Atlantic [13,14], which have been shown to be closely linked to orbitally forced changes in the ocean climate system. Here, we provide evidence of orbital forcing in the OAE2 intervals for the northwestern proto-North Atlantic Sites 105 and 603B using carbon isotope stratigraphy and spectral analysis. In addition, changes in geochemical parameters of two green-black-green claystone cycles were 


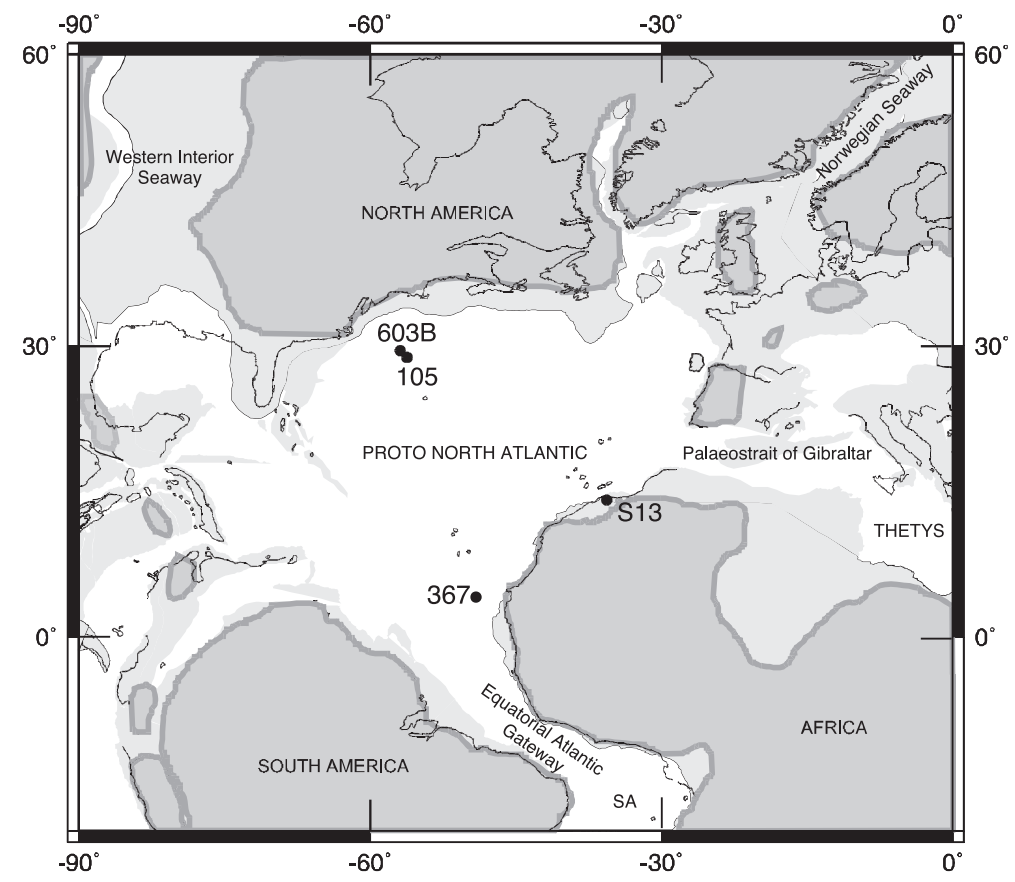

Fig. 1. Palaeogeographical map of the mid-Cretaceous ( $\sim 94 \mathrm{Ma})$ North Atlantic showing the position of the four studied cores. Light greyshaded regions represent flooded continental plates (from GEOMAR map generator; www.odsn.de/odsn/services/paleomap/paleomap.html). Dark grey-shaded regions represent land [64].

studied at high resolution, and the results are used together with the data obtained from overall geochemical analyses for the OAE2 interval to reconstruct orbitally forced chemocline variations and variations in primary productivity.

\section{Material and methods}

The sediment samples used in this study were obtained from the Deep Sea Drilling Project (DSDP) Sites 105 (Leg 11; core 9, sections 2-6) and 603B (Leg 93; core 33, section CC; core 34, sections 1-6) off the coast of North America. One- to five-centimeter-thick sediment slices were taken from the cores. Subsamples were taken from these slices and subsequently freeze dried and powdered in an agate mortar.

Analyses of soluble and insoluble organic matter and the major, minor and trace elements were performed, as described previously by Kuypers et al. [9]

$\mathrm{X}$-ray powder diffraction (XRD) was carried out on a home-built (NIOZ, Texel) high-accuracy $\theta-\theta$ diffractometer to determine the mineralogical compo- sition of the sediments. CuKá radiation $(40 \mathrm{kv}, 40$ $\mathrm{mA}$ ) from a long fine focus tube was applied in combination with variable divergence and antiscatter slits and an energy dispersive Si/Lidetector (Kevex). The measuring slit was set at $0.2 \mathrm{~mm}$, and the counting time was $1 \mathrm{~s} / 0.02^{\circ} 2 \theta$. The samples were $\mathrm{Ca}^{2+}$ exchanged prior to analysis. The samples were measured at $50 \%$ relative humidity [15]. The patterns were corrected for the Lorentz and polarisation factor and for the irradiated specimen volume.

Power spectra were obtained by using the CLEAN transformation of Roberts et al. [16] and the Blackman-Tukey method [17]. For the determination of the $95 \%, 90 \%$ and $80 \%$ significance levels associated with the frequency spectra of the CLEAN algorithm, we applied the Monte Carlo-based method developed by Heslop and Dekkers [18]. The CLEAN spectra for the TOC and HI depth series were determined by (I) $10 \%$ white noise addition (i.e., control parameter $=0.1$ ), (II) CLEAN algorithm gain factor of 0.1, (III) 500 CLEAN algorithm iterations, (IV) dt value of $0.02 \mathrm{~m}$ and (V) 1000 simulation iterations. The Blackman-Tukey power spectra were obtained by 
using the AnalySeries 1.1 software package of Paillard et al. [19]. In this case, data sets were equally spaced and prepared by removing the linear trends for the increasing TOC contents and HI values of the black claystones up-section. A band width of 0.389071 has been applied to smooth the spectrum.

\section{Results and discussion}

\subsection{Stratigraphy and palaeosetting}

Our study concentrates on the sediments of DSDP Sites 105 and 603B in the northern proto-North Atlantic (Fig. 1) that have been assigned a late Cenomanian to early Turonian age based on biostratigraphy $[11,20]$. Although these sites are only $\sim 125 \mathrm{~km}$ apart, their depositional history was different. Site 603B was located nearer to the coast and was characterized by hemipelagic sedimentation and influenced by coastal oceanic events, whereas Site 105 was dominated by pelagic sedimentation) [11]. Both sites, however, show the OM enrichment that characterizes $\mathrm{C} / \mathrm{T}$ sediments worldwide [11]. The $\mathrm{C} / \mathrm{T}$ sequences at DSDP Sites 105 and 603B consist of an alternation of OM-poor green claystones and OM-rich (TOC 1-25\%) black claystones [11]. Carbonate contents are low $(<10 \%)$, which suggests that deposition took place below the calcite compensation depth (CCD). The hemipelagic sediments of Site $603 \mathrm{~B}$ as well as the pelagic sediments of Site 105 were deposited at a water depth of $\sim 4000 \mathrm{~m}$ [21].

Carbon isotope stratigraphy was used to constrain the OAE2 interval and to correlate these abyssal sites with the Moroccan shelf site S13, a site with good bio- and chronostratigraphic control [22]. For a more thorough discussion of this method, see Kuypers et al. [9]. The horizontal dotted lines with Roman numerals (I-III) in the idealized representation of the $\mathrm{C} / \mathrm{T}$ stable carbon isotope excursion (Fig. 2) indicate the boundaries between the preexcursion conditions (i.e., preexcursion $\delta^{13} \mathrm{C}$ values) and the three main phases of the isotope excursion (i.e., rapid positive shift in $\delta^{13} \mathrm{C}$ values, plateau with maximum $\delta^{13} \mathrm{C}$ values and return to preexcursion $\delta^{13} \mathrm{C}$ values). Of particular stratigraphic significance is boundary II that nearly coincides with the last occurrence of the planktonic foraminifer Rotalipora cushmani [23] and

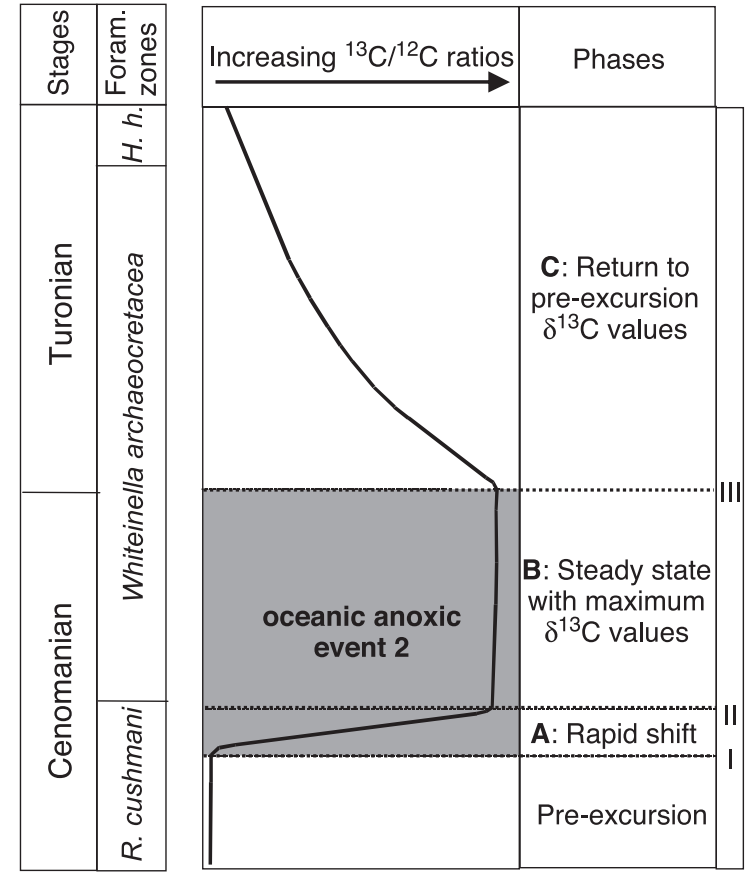

Fig. 2. Idealised representation of Cenomanian/Turonian (C/T) stable carbon isotope excursion showing the biostratigraphic position of the three main phases (modified after [24]). Dashed lines with roman numbers show the position of the boundaries between the different phases (preexcursion, $[\mathrm{A}-\mathrm{C}]$ ) of the isotope excursion.

boundary III, which approximately coincides with the $\mathrm{C} / \mathrm{T}$ boundary $[24,25]$. The positive excursion in $\delta{ }^{13} \mathrm{C}$ values reflects a change in the global atmospheric oceanic pool of inorganic carbon resulting from a global increase in the burial rate of ${ }^{13} \mathrm{C}$ depleted OC [2]. By definition, the OAE2 is the main phase of enhanced carbon burial rates and, therefore, should be coeval with the interval between boundaries I and III (phases A and B indicated as a grey-shaded area in Fig. 2).

The use of molecular fossils that are specific for primary producers instead of bulk OM for stable carbon isotope stratigraphy greatly reduces the effect of heterotrophy, preservation and diagenetic alteration on the carbon isotopic signature of OC [26-28]. At Site 603B, the stable carbon isotopic composition of the acyclic isoprenoid phytane released upon desulfurisation of the polar fraction (e.g., S-bound phytane) was used for carbon isotope stratigraphy (Fig. 3). This Sbound phytane mainly derives from the phytol moiety of phytoplanktonic chlorophyll and, thus, reflects the 


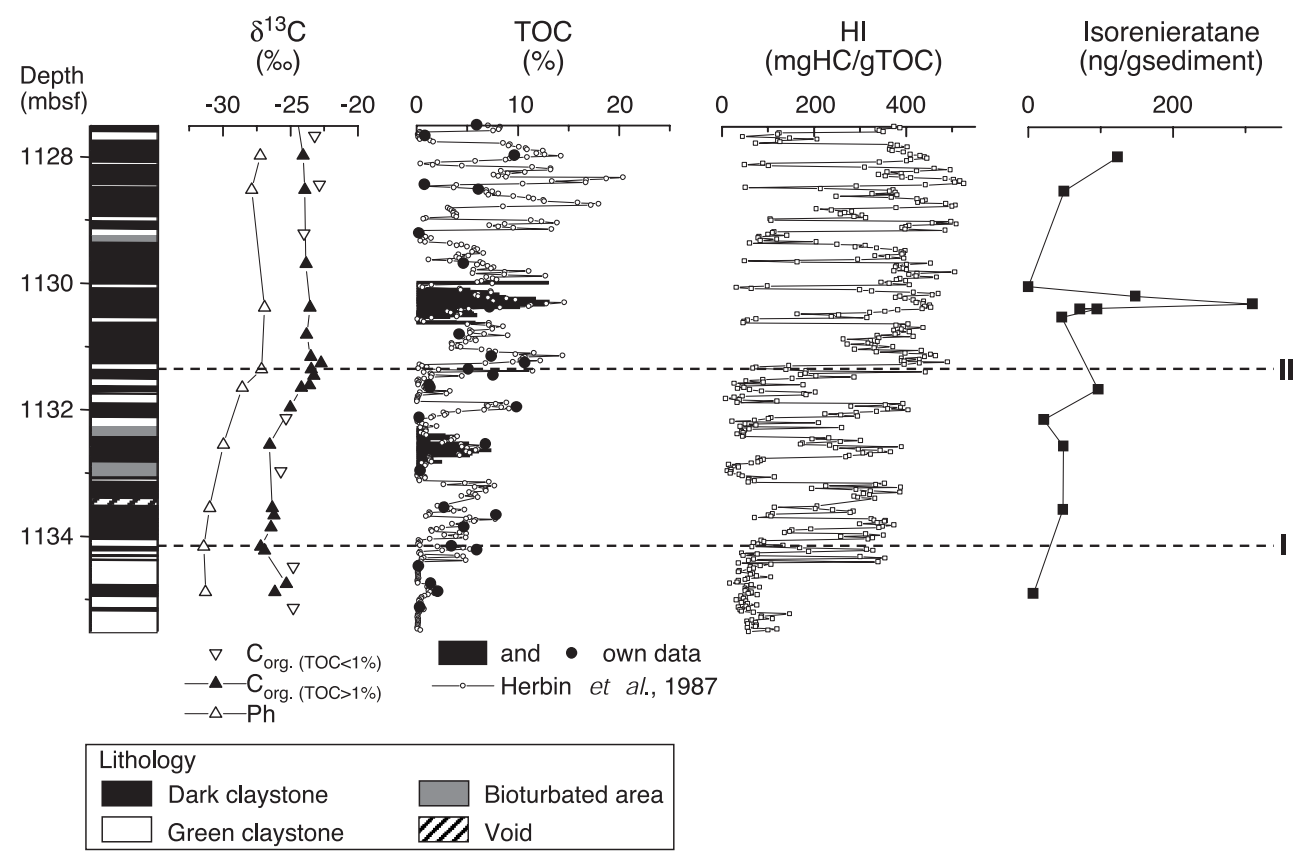

Fig. 3. Stratigraphy, biomarker and bulk organic carbon data of DSDP Site 603B. Carbon isotope values (in \%o vs. VPDB) of $\mathrm{C}_{\text {org }}, \mathrm{S}-\mathrm{bound}$ phytane $(\mathrm{Ph})$ derived from phytoplanktonic chlorophyll, TOC content and HI indices of the bulk sediment (own data and data previously reported by Herbin et al. [11]). The dashed lines with roman numbers show the approximate position of the boundaries between the different phases (i.e., rapid positive shift in $\delta{ }^{13} \mathrm{C}$ values, plateau with maximum $\delta^{13} \mathrm{C}$ values and return to preexcursion $\delta^{13} \mathrm{C}$ values) of the carbon isotope excursion.

changes in the stable carbon isotopic composition of phytoplankton [29]. The $\delta^{13} \mathrm{C}$ profile for S-bound phytane (i.e., $\mathrm{Ph}$ ) at Site 603B shows the rapid shift in ${ }^{13} \mathrm{C} /{ }^{12} \mathrm{C}$ ratios that marks phase $\mathrm{A}$, as well as at least a part of phase $\mathrm{B}$ (the plateau with maximum $\delta^{13} \mathrm{C}$ values; Fig. 3). The latter part of phase B, most of phase $\mathrm{C}$ and boundary III are obscured by a coring gap (Fig. 7). The isotopic record of TOC indicates that sediments with a TOC $<1 \%$ are generally $1-3 \%$ o enriched in ${ }^{13} \mathrm{C}$ relative to adjacent sediments with a TOC $>1 \%$ (Fig. 3). This indicates that preservation could have affected the bulk OC $\delta^{13} \mathrm{C}$ record. However, if we exclude the $\delta^{13} \mathrm{C}$ values of samples with a $\mathrm{TOC}<1 \%$, there is a general similarity in trend between the molecular fossil and bulk $\mathrm{OC} \delta^{13} \mathrm{C}$ records for the OAE2 interval (phases A and B) at Site 603B. The offset of $\sim 3 \%$ o between $\delta^{13} \mathrm{C}$ profiles for bulk OC and the molecular fossils of chlorophyll in this interval is well within the range reported for extant algae [30]. This offset is significantly larger $(4-5 \%$ ) in the preexcursion interval, which we also attribute to selective preservation (see Section 3.2.3). As a consequence, the $\delta^{13} \mathrm{C}$ excursion is $\sim 1 \%$ o smaller for bulk OC than for S-bound $\mathrm{Ph}$ (Fig. 3). The $\delta^{13} \mathrm{C}$ excursion for bulk $\mathrm{OC}$ at Site 105 is comparable in magnitude $(\sim 3 \%)$ to Site 603B (Fig. 4). Although there is no significant coring gap at Site 105 , phase A and part of phase $\mathrm{B}$ can be distinguished. Phase $\mathrm{C}$ and boundary III could not be distinguished at Site 105 due to the extremely low abundance of marine OC in the base of the Plantagenet Formation (Fig. 7).

\subsection{Cyclic variations in abundance and source of the sedimentary $O M$}

\subsubsection{Cyclic variations in TOC content and Rock} Eval hydrogen and oxygen indices

The late Cenomanian sediments of DSDP Sites 105 and 603B contain high amounts of OC with maximum TOC values of $\sim 26 \%$ (Figs. 3 and 4; [11]). During the OAE2, the average TOC contents at both sites are significantly higher $(5-6 \%)$ than before $(\sim 2 \%)$. At both sites, this increase in TOC content is accompanied by a significant increase in Rock Eval 


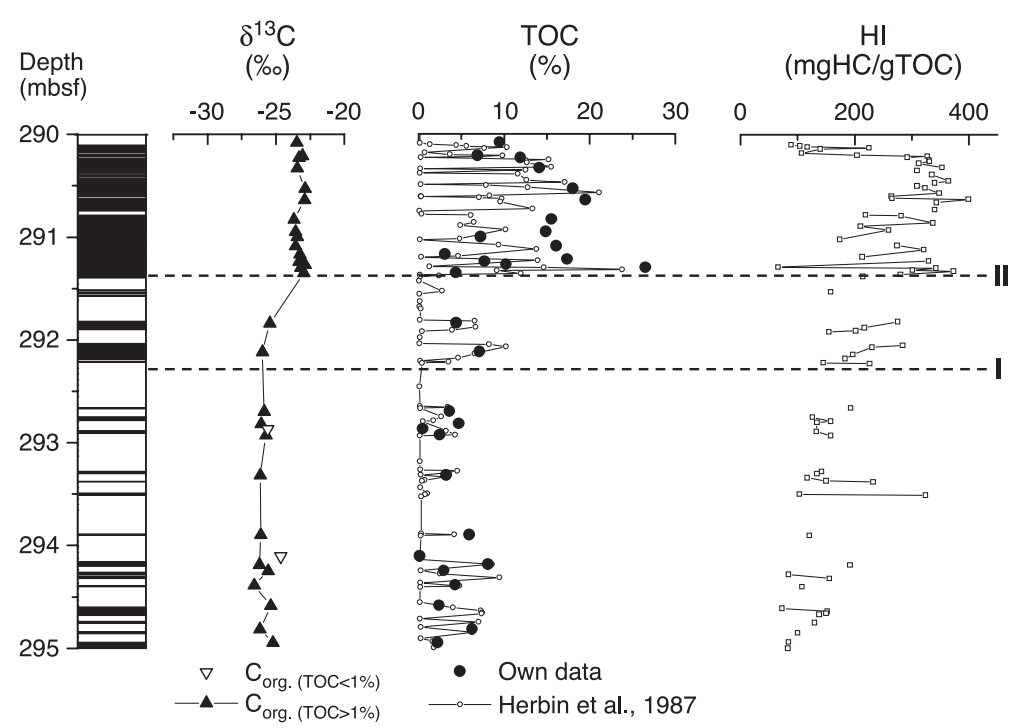

Fig. 4. Stratigraphy and bulk organic carbon data of DSDP Site 105. Carbon isotope values (in \%o vs. VPDB) of $\mathrm{C}_{\text {org }}$, TOC content and HI indices of the bulk sediment (own data and data previously reported by Herbin et al. [11]). The dashed lines with roman numbers show the approximate position of the boundaries between the different phases (i.e., rapid positive shift in $\delta^{13} \mathrm{C}$ values, plateau with maximum $\delta^{13} \mathrm{C}$ values and return to preexcursion $\delta^{13} \mathrm{C}$ values) of the carbon isotope excursion.

hydrogen indices (HI) from $\sim 150 \mathrm{mg}$ hydrocarbons $/ \mathrm{g}$ TOC before to $\sim 270 \mathrm{mg}$ hydrocarbons/g TOC during the OAE2 (Figs. 3 and 4; [11]). Superimposed on these long-term trends are high amplitude, short-term cyclic variations in both TOC content and HI values throughout the investigated sections (Figs. 3 and 4). The more pronounced changes in TOC contents and HI values are also reflected by changes in lithology from green claystones with low TOC contents and HI values to black claystones with high TOC contents and $\mathrm{HI}$ values. HI values are generally $<100 \mathrm{mg}$ hydrocarbons/g TOC and oxygen indices (OI) high $(\mathrm{OI}>100)$ for the OM-lean green claystones, which has been attributed to a terrestrial source for the OC [11]. In sharp contrast, high HI values and low OI values [11] indicate a predominately marine origin for the thermally immature $\mathrm{OM}$ for the OC-rich black claystones. To resolve the sources of the sedimentary OM, both the extractable and insoluble OMs were also investigated on a molecular level.

\subsubsection{Cyclic variations in organic matter composition at the molecular level}

Only small amounts of total extracts were recovered from the OM-lean sediments outside the black shale interval (1.0 to $2.0 \mathrm{mg} / \mathrm{g}$ dry sediment), while higher amounts ( 4.0 to $8.0 \mathrm{mg} / \mathrm{g}$ dry sediment) were recovered from the black shales. The hydrocarbon fractions from the OM-rich black claystones consist mainly of short-chain $n$-alkanes $\left(\mathrm{C}_{16}-\mathrm{C}_{22}\right)$ with no odd-over-even carbon number predominance, longchain $\left(\mathrm{C}_{25}-\mathrm{C}_{35}\right) n$-alkanes with a moderate odd-overeven carbon number predominance (CPI 1.8), hopanoids, steroids and acyclic isoprenoids (Fig. 5a). Steroids and hopanoids strongly dominate these hydrocarbon fractions. The hydrocarbon fractions from the OM-lean green claystones (Fig. 5b) are strongly dominated by short-chain $n$-alkanes $\left(\mathrm{C}_{16^{-}}\right.$ $\mathrm{C}_{22}$ ) with no odd-over-even predominance and longchain $\left(\mathrm{C}_{25}-\mathrm{C}_{35}\right) n$-alkanes with a moderate odd-overeven carbon number predominance (CPI 1.8).

The steroids in the black claystones derive predominately from cholesterol, 24-methyl-cholesterol and 24-ethyl-cholesterol or their unsaturated derivatives, which are predominately biosynthesized by marine algae [31]. However, zooplankton could be a significant source for the $\mathrm{C}_{27}$ steroids because cholesterol and its derivatives $\left(\mathrm{C}_{27}\right.$ sterols $)$ are also indirectly formed by dealkylation of ingested $\mathrm{C}_{28}$ and $\mathrm{C}_{29}$ sterols [32] by zooplankton heterotrophically living on algal biomass. The hopanoids are likely 


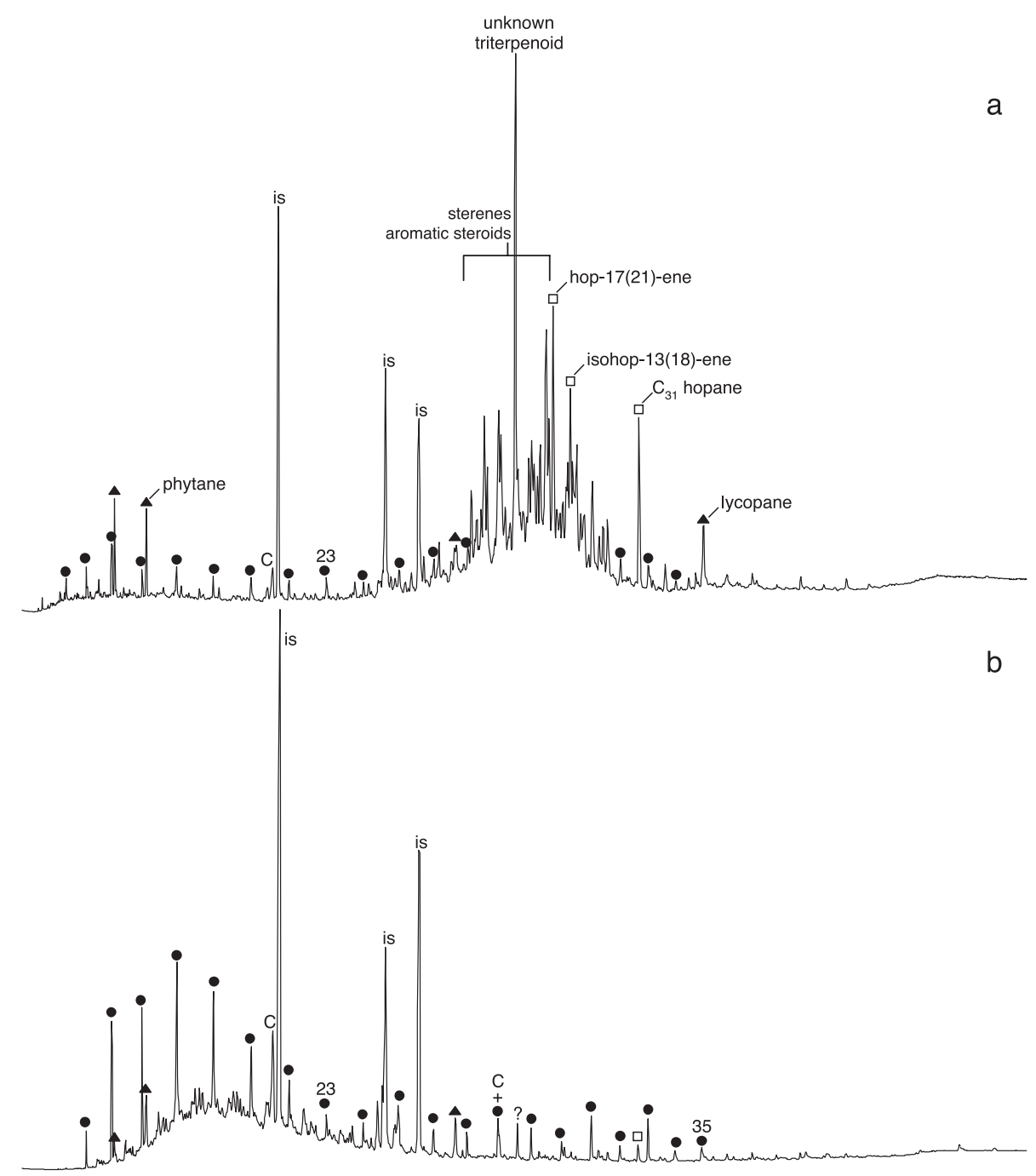

Fig. 5. Typical reconstructed total mass chromatogram [i.e., total ion count (TIC)] of apolar fractions of black claystones (a) and of green claystones (b) of DSDP Site 603B. Filled circles $(\bullet)$, open squares $(\square)$ and filled triangles $(\boldsymbol{\Delta})$ indicate $n$-alkanes, hopanes and saturated acyclic isoprenoids, respectively. Abbreviations are is - internal standard; $23-n-\mathrm{C} 23$; $35-n-\mathrm{C} 35$; C—contaminant; ?-compounds of unknown structure.

diagenetic products of hopanols such as bacteriohopanopolyol derivatives $\left(\mathrm{C}_{35}\right)$ or diplopterol (hopanes $=\mathrm{C}_{30}$ ) and may derive from numerous bacterial taxa, such as cyanobacteria, heterotrophic bacteria and methanotrophic bacteria [33]. The odd-over-even predominance (CPI $\sim 1.8$ ) of the $n-\mathrm{C}_{25}$ to $n-\mathrm{C}_{35}$ alkanes suggests that leaf waxes of terrestrial plants are an important source for the long-chain $n$-alkanes [34], while the short-chain $n$-alkanes $\left(\mathrm{C}_{16}-\mathrm{C}_{22}\right)$ with no odd-over-even predominance are nonspecific and could derive from a wide variety of algae and bacteria.

Because functionalised lipids and carotenoids may become sulfurised during early diagenesis in anoxic sulfide-rich sediments, e.g., see [35], the polar fractions were desulfurised. The apolar fractions obtained after desulfurisation of the polar fractions from the black claystones are mainly dominated by phytane of phytoplanktonic origin and bacterially derived extended (i.e., $>\mathrm{C}_{30}$ ) hopanoids. These 
hopanoids are typically dominated by the $\mathrm{C}_{33}$ and $\mathrm{C}_{35}$ 2-desmethyl-17 $\beta, 21 \beta(\mathrm{H})$ hopanes and their coeluting $2 \beta$-methyl- $17 \beta, 21 \beta(\mathrm{H})$ isomers. On average, these hopanoids together make up $60 \%$ to $80 \%$ of the extended hopanes present in the black claystones. The abundance of 2-methylhopanoids relative to desmethylhopanoids indicates that cyanobacteria are an important source of these molecular fossils [36,37]. In contrast, the apolar fractions obtained after desulfurisation of the polar fractions from the green claystones are mainly dominated by $n$-alkanes with no obvious odd-over-even predominance.

In conclusion, the low abundance of molecular fossils of unambiguous terrestrial origin (e.g., leaf wax lipids and oleananes) relative to biomarkers of marine origin (e.g., algal steroids and hopanoids derived from cyanobacteria) supports a predominately marine phytoplanktonic source for the $\mathrm{OM}$ of the black claystones. The higher relative abundance of leaf wax $n$-alkanes, on the other hand, is in good agreement with a mainly terrestrial source for the OM of the green claystones.

Thermal degradation (flash pyrolysis) in combination with gas chromatography was used to investigate the sources of the insoluble OM, representing $>90 \%$ of the TOC. In accordance with the extremely low $(<100 \mathrm{mg} \mathrm{HC} / \mathrm{gTOC})$ Rock Eval HI indices, no detectable amounts of hydrocarbons were released from the green claystones. Pyrolysis of the decalcified black claystone samples, however, released considerable amounts of hydrocarbons with $n$-alkenes $/ n$ alkanes, alkylbenzenes and alkylthiophenes as the main products. These compounds also dominate the pyrolysates from the OAE2 black shales of the southern part of the proto-North Atlantic [Kuypers et al., unpublished results] and from ancient marine kerogens in general, e.g., see $[28,38,39]$. The extremely low abundance of lignin thermal degradation (pyrolysis) products generated from the kerogen supports a predominately marine origin for the OM from the black claystones of Sites 105 and 603B.

\subsubsection{The effect of cyclic variations in the OM source on $\delta^{13} C_{\text {org }}$}

There is a significant difference in $\delta^{13} \mathrm{C}$ values for bulk OM between adjacent OM-lean green and OMrich black claystones, with the former being enriched in ${ }^{13} \mathrm{C}$ (up to $2 \%$ ) relative to the black claystones
(Figs. 3 and 4). In the late Cenomanian interval preceding the isotope excursion, the $\delta^{13} \mathrm{C}_{\text {org }}$ values even show a moderate negative correlation with TOC $\left(r^{2}=0.78\right)$. This dependence of $\delta^{13} \mathrm{C}_{\text {org }}$ on TOC $\left(r^{2}=0.78\right)$ is also observed during and after the OAE2 carbon isotopic excursion after 'detrending' the $\delta^{13} \mathrm{C}_{\text {org }}$ values for the isotope excursion by subtracting the $\delta^{13} \mathrm{C}$ values for the marine biomarker S-bound phytane. A similar negative correlation has previously been observed for $\delta^{13} \mathrm{C}_{\text {org }}$ and $\mathrm{HI}$ for early and middle Cretaceous marine sediments and was attributed to variations in the relative contribution of refractory terrestrial and marine OM [40]. In modern marine environments, $\delta{ }^{13} \mathrm{C}$ values for marine $\mathrm{OM}$ are commonly more positive than for terrestrial OM. However, during most of the Cretaceous, elevated $\mathrm{pCO}_{2}$ levels resulted in an increase in the isotope effect associated with carbon fixation $\left(\varepsilon_{\mathrm{p}}\right)$ by phytoplankton, leading to $\delta^{13} \mathrm{C}$ values for marine $\mathrm{OM}$ that were generally more negative than for terrestrial $\mathrm{OM}$ [40]. The negative correlations between TOC and $\delta^{13} \mathrm{C}_{\text {org }}$ values at Sites 105 and $603 \mathrm{~B}$, therefore, most likely can be attributed to an increased terrestrial contribution to the green claystones relative to the black claystones.

\subsection{Sedimentary cycles and orbital forcing}

Power spectra for the TOC and HI depth series of DSDP Site 603B-34, sections 1-6 [11] reveal distinct peaks at $\sim 0.40, \sim 0.75$ and $\sim 2.80 \mathrm{~m}$ and two less significant peaks at $\sim 0.59$ and $\sim 1.22$ m (Fig. 6). An additional peak is detected at $\sim 10.6 \mathrm{~m}$ by the CLEAN algorithm only. This peak can be explained by the trend in the data sets. The Blackman-Tukey power spectra do not show this peak because the trend had been removed from the dataset before the spectral analysis. Minor peaks are also recorded in the 0.25 $0.16 \mathrm{~m}$ band but are not significant at the $90 \%$ significance level (Fig. 6). We have plotted the original $\mathrm{HI}$ and TOC data (dotted line) as well as the CLEANed (solid lines; significance level of 90\%) data sets against depth and compared them with the $\delta^{13} \mathrm{C}_{\text {phytane }}$ record in Fig. 7. Clearly, the $\sim 0.40 \mathrm{~m}$ cycle becomes increasingly important in both $\mathrm{HI}$ and TOC records above boundary II, whereas the $\sim 0.75 \mathrm{~m}$ cycle determines the main pattern in the interval below this boundary. The metric scale cyclicity $(\sim 1.22 \mathrm{~m})$ 

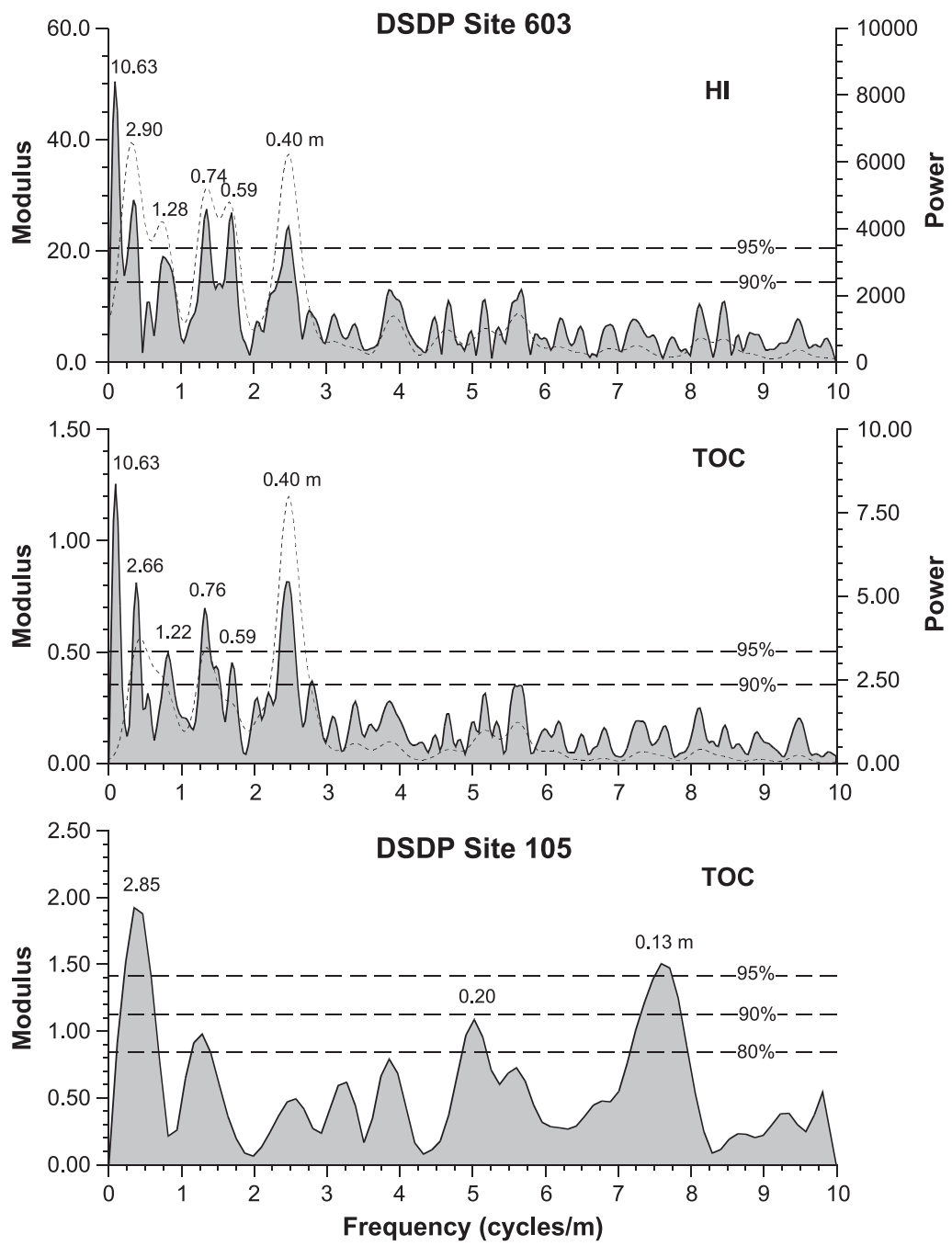

Fig. 6. Spectra for TOC and HI of DSDP Sites 603 and 105 obtained by the Monte Carlo CLEAN procedure (solid) and the Blackman-Tukey method (dashed). Indicated are the most prominent cycles in meters. TOC and HI data are from Herbin et al. [11].

becomes more prominent in the spectra than the $\sim 0.75$ $\mathrm{m}$ cycle when only the upper interval (above boundary II) is taken into account (not shown). The length of this period, however, slightly increases toward $\sim 1.6 \mathrm{~m}$, thereby approximating the length of three to four $0.40 \mathrm{~m}$ cycles.

Fig. 6 also shows the CLEANed power spectrum for the TOC depth series of DSDP Site 105-9, sections 3-4 [11], i.e., the counterpart of the analyzed interval at Site 603B. The spectrum reveals strong peaks at $\sim 2.85$ and $\sim 0.13 \mathrm{~m}$ and a minor peak at $\sim 0.2 \mathrm{~m}$. The $\sim 2.85$-m peak reflects the general trend of increasing
TOC contents up-section. We plotted the CLEANed TOC data set of Site 105 and compared it in the depth domain with that of Site 603B (Fig. 7). We used the $80 \%$ significance level for this reconstruction to include the influence of the $\sim 0.2 \mathrm{~m}$ cycle. It seems obvious that the $\sim 0.13$ and $\sim 0.2 \mathrm{~m}$ cycles of Site 105 correlate with the $\sim 0.4$ and $0.75 \mathrm{~m}$ cycles of Site 603B, respectively (Fig. 7). Ten TOC maxima can be recognized in the interval between boundary II and the base of the Plantagenet Formation at $290.1 \mathrm{~m}$. The influence of the $\sim 0.2 \mathrm{~m}$ cycle seems more prominent during phase A. 


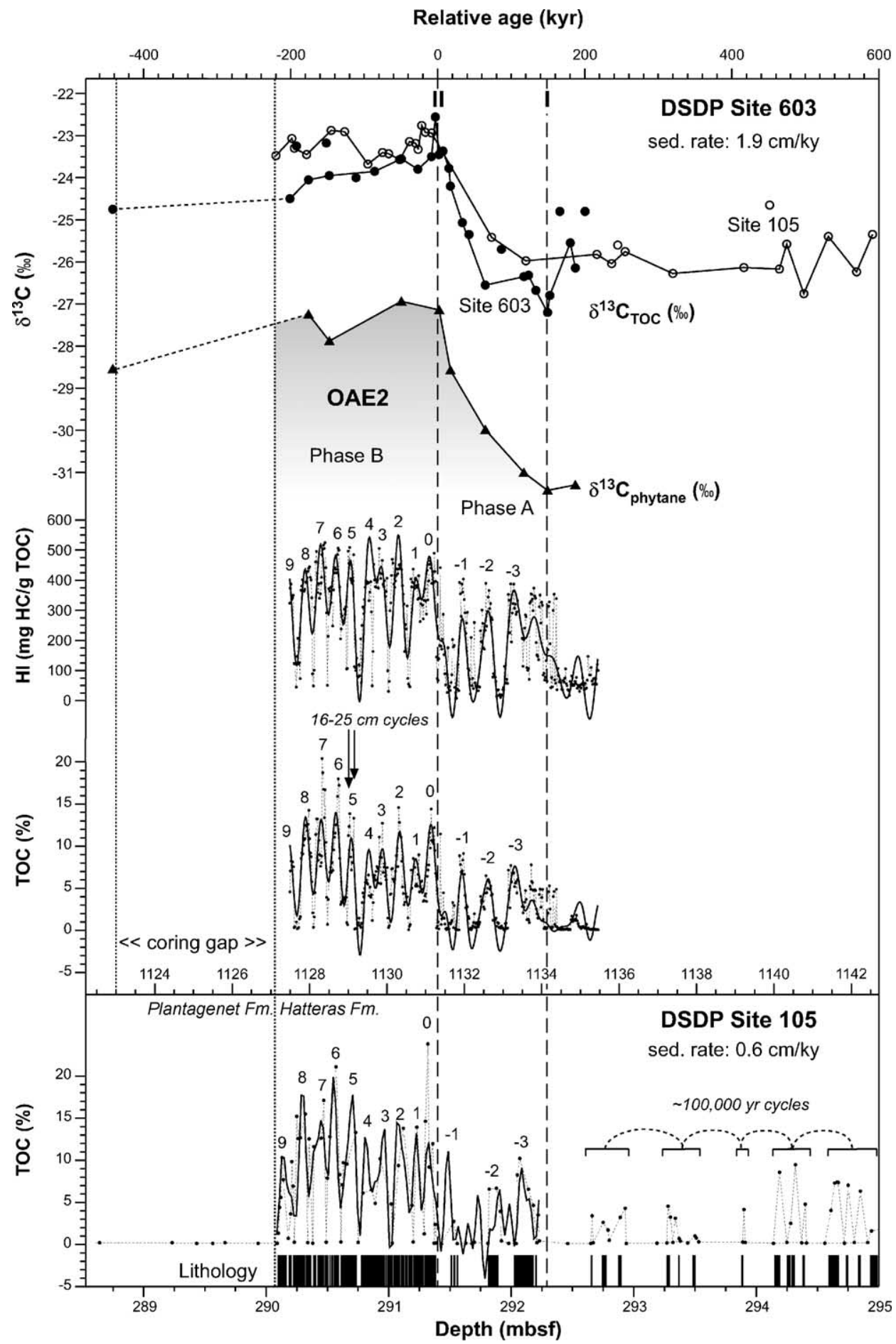

Fig. 7. Orginal and CLEANed (at the $90 \%$ significance level) TOC and $\mathrm{HI}$ series against depth and time across OAE2 and the $\delta^{13} \mathrm{C}$ shift. For the depth to age conversion, a constant sedimentation rates of 1.9 and $0.6 \mathrm{~cm} / \mathrm{kyr}$ have been applied for DSDP Sites 603 and 105 respectively. Lithology (i.e., distribution of black claystones vs. depth at Site 105), TOC and HI data are from Herbin et al. [11]. 
Black-colored organic-enriched claystones alternating with green-colored organic-poor claystones also occur in the lower part of core 9 of Site 105 (sections 5 and 6: 292.5-295 mbsf; Figs. 4 and 7). The spacing between these individual TOC-enriched darkcolored layers is very regular $(0.11-0.13 \mathrm{~m})$ and consistently showing their cyclic occurrence. Unfortunately, the resolution of the TOC record is too low for this interval to apply spectral analysis (that is, the average sample spacing of $\sim 6.2 \mathrm{~cm}$ for this interval results in a Nyquist frequency of $12.4 \mathrm{~cm}$ which equals that of the regular cycle thickness). But evidently, the black layers are grouped (one to four black layers per group), pointing to a lower frequency modulation (Figs. 4 and 7). These cyclic patterns are reminiscent of the rhythmical bedding related to the Milankovitch periodicities that are observed in Pleistocene to Mesozoic sediments (i.e., see $[41,42]$ ). Accordingly, it seems likely that the $0.11-0.13 \mathrm{~m}$ cycle in Site 105 reflects the precession $(\sim 21,000$ year) cycle, whereas the groups of one to four black layers reflect the 100-kyr eccentricity modulation. The variation in number (one to four) of precession-related black layers per group are in turn (i.e., see $[12,42]$ ) attributed to the influence of the 400-kyr eccentricity modulation. Both the 100-kyr and 400-kyr eccentricity cycles modulate the climatic precession, which should have triggered the deposition of these dark layers through insolation and, hence, climate changes. At times of a 400-kyr eccentricity minimum, the effect of the $100 \mathrm{kyr}$ on precession is smaller than during a 400-kyr eccentricity maximum. For example, the deposition of groups of three to four PliocenePleistocene sapropels was shown to be associated with 400-kyr eccentricity maxima, while 400-kyr eccentricity minima were associated with the deposition of zero to two individual sapropels $[12,41]$. Accordingly, the groups of three to four individual black layers in the lower part of core 9 of Site 105 cycle may reflect $100 \mathrm{kyr}$ cycles during 400-kyr eccentricity maxima, whereas one to two black layers may reflect $100 \mathrm{kyr}$ cycles during or close to a 400kyr eccentricity minimum (Figs. 4 and 7). The interpretation of approximately four short eccentricity-related cycles $(\sim 100 \mathrm{kyr}$ each; $\sim 400 \mathrm{kyr}$ in total or one long eccentricity cycle) in $\sim 2.4 \mathrm{~m}$ indicates an average sedimentation rate of $0.6 \mathrm{~cm} / \mathrm{kyr}$ for the lower part of core 9 of Site 105 . The occurrence of similar decimeter scale cycles in the upper interval suggests that these cycles are controlled by the precession cycle as well, and that sedimentation rates $(\sim 0.13 \mathrm{~m}$ cycle divided by $\sim 21 \mathrm{kyr}=0.5-0.6 \mathrm{~cm} / \mathrm{kyr}$ ) on average did not change substantially within this time interval. This would also imply that the $\sim 0.4 \mathrm{~m}$ TOC and HI cycles at Site 603B are precession related, and that the sedimentation rate at this site is in the order of $1.9 \mathrm{~cm} /$ kyr during this time interval. As a result, the $\sim 0.75 \mathrm{~m}$ cycle at Site $603 \mathrm{~B}$ and $\sim 0.2 \mathrm{~m}$ cycle at Site 105 probably reflect the influence of the obliquity $(\sim 39.5$ kyr) cycle. Apparently, the obliquity cycle seems to be of primary importance at times of the (initial) shift in the $\delta^{13} C_{\text {phytane }}$ record toward heavy values.

In general, sedimentary successions that are primarily controlled by the precession cycle (and eccentricity modulation) record the additional influence of obliquity in periods when one of the longterm eccentricity cycles (i.e., $\sim 0.4$ and $\sim 2.3 \mathrm{Myr}$ cycles) is at a minimum. In such cases, insolation time series are marked by distinct precessionobliquity interference patterns causing the amplification and reduction of two successive precession cycles. In combination with an on average reduced precession period during these times, this may result in the occurrence of double cycles of different duration (i.e., see [12]). We suggest that the pattern observed in the TOC and HI records during the initial shift (phase A) is related to an analogous period of low eccentricity values.

Given the estimated average sedimentation rates for Sites 603B and 105 of 1.9 and $0.6 \mathrm{~cm} / \mathrm{kyr}$, respectively (Fig. 7), the duration for the initial shift in the $\delta^{13} \mathrm{C}_{\text {phytane }}$ record (phase A) is approximately $\sim 150,000$ years, whereas the steady state with

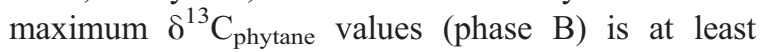
220,000 years. A coring gap obscuring the later part of the phase B (plateau with maximum $\delta^{13} \mathrm{C}$ values) at Site 603B does not allow the duration of the whole OAE2 to be calculated (Fig. 7). Although no coring gap occurs at Site 105, the duration for the whole OAE2 could not be calculated because phase $\mathrm{C}$ (return to preexcursion $\delta^{13} \mathrm{C}$ values) could not be distinguished (Fig. 7). However, our estimation of $\sim 150,000$ years for phase A (Fig. 7) is in good agreement with the recent estimate of $\sim 150 \mathrm{kyr}$ by Kolonic et al. [22], which is based on the recognition of 1.5 dominant eccentricity cycles within the high 
sedimentation rate records of the Tarfaya Basin (Morocco) during this time interval.

\subsection{Preservation vs. productivity}

The presence of precession cycles in the sediment record is often attributed to productivity changes, resulting from climatic changes, such as monsoonal intensity. However, the strong variations in $\mathrm{HI}$ values and TOC content for $\mathrm{C} / \mathrm{T}$ sediments from Sites 105 and 603B have been previously attributed to fluctuations in redox conditions of the bottom waters [11]. To test whether enhanced $\mathrm{OM}$ preservation resulting from either reduced oxygen supply and/or enhanced productivity caused this variation in TOC/HI values, two OM-poor green to OM-rich claystone couplets (i.e., cycle -2 of phase A and cycle 2 of phase B; Fig. 7) at Site 603B were studied in greater detail (Fig. 8). The $\mathrm{C}_{\text {org }}(\%)$ data for cycles -2 and 2 are comparable to what has been reported by Herbin et al. [11] for these particular intervals (Fig. 3).

\subsubsection{Water column redox proxies}

The deposition of laminated sediments and the absence of benthic foraminifers at Site 603B indicates predominantly suboxic to anoxic bottom water con- ditions during the deposition of both green and black claystones $[11,43]$. However, the occurrence of thin $(10-20 \mathrm{~cm})$ bioturbated layers in the green claystones (Fig. 3; [11]) indicates the periodic occurrence of oxic bottom water conditions during the deposition of green claystones.

Further information on water column redox conditions can be gained from chalcophilic elements (e.g., $\mathrm{Mo}, \mathrm{Ni}$ and $\mathrm{Zn}$ ) that precipitate as sulfides under euxinic conditions and certain redox sensitive elements (e.g., Mo and V) that are immobilised under reducing conditions [44]. In a similar way, Mn, which is mobilised under reducing (anoxic) conditions and precipitates as oxyhydroxides under oxic conditions, can provide information about redox conditions of the bottom waters [45]. To evaluate the variations in redox conditions, the abundances of $\mathrm{Mn}, \mathrm{Mo}, \mathrm{V}$ and $\mathrm{Zn}$ have been normalized to aluminum (Fig. 8). Al is mainly present in clay minerals, and although the $\mathrm{Al}$ content in clay minerals can vary, normalisation to Al is frequently used [46] to correct for fluctuations in detrital contribution. We investigated the trace metal content of cycles -2 (strong obliquity influence) and 2 (precession dominated) representing the two main orbital phase relations (see Section 3.3) of the OAE2 interval at Site $603 \mathrm{~B}$ at high resolution. The low

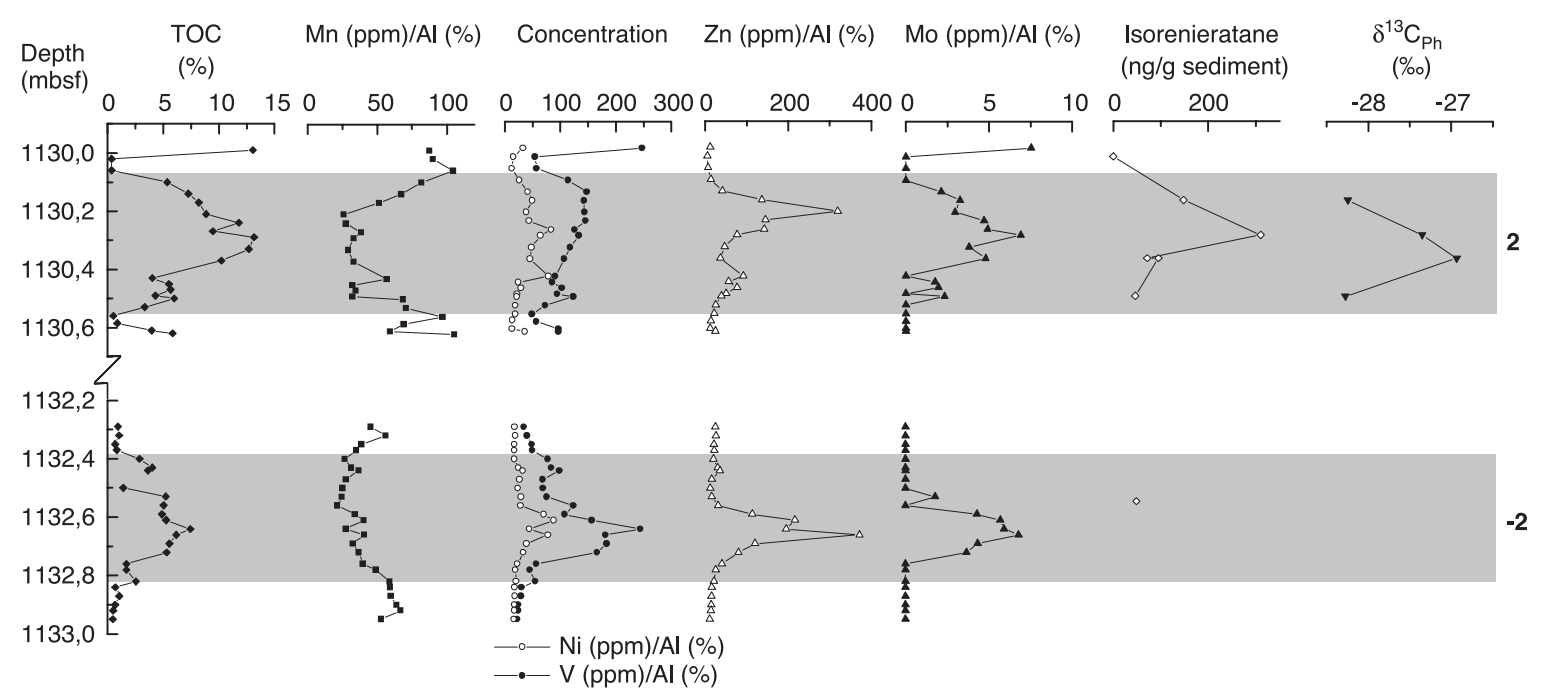

Fig. 8. Bulk organic carbon, trace metal and biomarker data of DSDP Site 603B. TOC content of the bulk sediment, concentration profiles of redox sensitive trace metals ( $\mathrm{Mn}, \mathrm{Mo}, \mathrm{Zn}$ and $\mathrm{V}$ ) normalised to $\mathrm{Al}$, concentration profile of the molecular fossil isorenieratane of green sulfur bacteria, and carbon isotope values (in \%o vs. VPDB) of S-bound phytane (Ph) derived from phytoplanktonic chlorophyll. The shaded areas show the approximate position of the black claystones of cycles -2 and 2 (see also Figs. 3 and 7). There are no $\delta^{13} \mathrm{C}$ values for S-bound Ph available for cycle -2 . 
abundance of $\mathrm{Mn}$ in cycles -2 and 2 relative to the adjacent OM-lean intervals indicates that the OM-rich intervals were deposited under generally more reducing suboxic/anoxic conditions (Fig. 8). The difference in $\mathrm{Mn} / \mathrm{Al}$ ratios between green and black claystones could have been further enhanced by Mn mobilisation in the reducing anoxic OM-rich intervals and subsequent reprecipitation as $\mathrm{Mn}$ oxyhydroxides on reencountering oxygen at the ancient oxidation front [45]. The high $\mathrm{Mo} / \mathrm{Al}, \mathrm{V} / \mathrm{Al}$ and $\mathrm{Zn} / \mathrm{Al}$ ratios in the cycles -2 and 2 (Fig. 8) indicate more reducing anoxic bottom water conditions during the deposition of the black claystones $[46,47]$. A similar enrichment in redox-sensitive trace metals is also observed for several other black claystones from Site 603B (Supplementary material, Table S1).

Additional evidence for different redox conditions of the bottom water during the deposition of the green and black claystones comes from the sedimentary biomarker record. Oxygen exposure time significantly affects the biomarker distribution, with an increasing contribution of more refractory biomarkers, such as terrestrial $n$-alkanes, relative to more labile biomarkers, such as steroids, with increasing exposure to oxygen $[48,49]$. The green claystones are dominated by the refractory terrestrial $n$-alkanes, while the labile hopanoids, steroids and lycopane are only present in trace amounts (Fig. 5b). This is indicative of long oxygen exposure times and, hence, oxygenated bottom waters $[48,50]$. The dominance of labile steroids and hopanoids in the apolar fractions of the black claystones (Fig. 5b), on the other hand, indicates relatively short oxygen exposure times, which is in good agreement with more anoxic bottom waters.

To investigate whether these anoxic conditions extended into the photic zone, the samples from DSDP Site 603B were examined for fossil derivatives of specific pigments (isorenieratene) of the browncolored strain of green sulfur bacteria (Chlorobiaceae). These photosynthetic bacteria require both light and $\mathrm{H}_{2} \mathrm{~S}$ for inorganic carbon fixation and are, therefore, indicators for photic zone anoxia. At the present day, the habitat for green sulfur bacteria is restricted to a few euxinic basins, such as the Black Sea $[51,52]$. Sinninghe Damsté and Köster [8] showed that during the mid-Cretaceous OAE2, these organisms were also present in the proto-North Atlantic
Ocean. More recently, we showed that green sulfur bacteria were already present in the southern part of the proto-North Atlantic well before the OAE2 [9]. Molecular fossils of isorenieratene (e.g., isorenieratane) were found in the black claystone intervals of cycles $-3,-2,0,2,6$ and 8 of Site 603B in concentrations of 7-300 ng/g sediment (Fig. 3). This indicates that sulfide-containing water sometimes penetrated the photic zone before as well as during the OAE2. Small amounts of isorenieratane $(21 \mathrm{ng} / \mathrm{g}$ sediment) were also found in the green claystone just above cycle -2 (Fig. 3). We believe that the isorenieratane in this green claystone derives from thin TOC-rich interlayers in this green claystone (Fig. 3).

Isorenieratane was found in cycle 2, with highest concentrations in the center of this black claystone while isorenieratane concentrations were below the detection limit in the overlying green claystone (Fig. 8). The latter is in good agreement with the green claystones being deposited under oxic conditions. The isorenieratane maximum could have resulted from substantially higher anoxygenic productivity in the water column of the northern proto-North Atlantic. In accordance with this, fluctuations in the abundances of isorenieratene extracted from Holocene Black Sea sediments were attributed to changes in anoxygenic productivity related to fluctuations in the position of the chemocline [53]. The abundance of phototrophic sulfur bacteria in modern settings shows a strong positive correlation with light intensity [54]. Thus, the apparent positive correlation between TOC content and abundance of isorenieratane within cycle 2 could indicate that enhanced $\mathrm{OM}$ accumulation was accompanied by a rise of the average position of the chemocline (i.e., nearer to the photic zone) during its deposition. This seems to be supported by a cooccurring increase in $\mathrm{Mo} / \mathrm{Al}$ ratios (Fig. 8).

\subsubsection{Productivity proxies}

Evidence for enhanced primary production during the deposition of the black claystone intervals of cycles -2 and 2 is provided by their mineralogical composition. The black claystones contain abundant opal CT, which is a diagenetic product of biogenic opal (Fig. 9). Biogenic opal is predominately produced by diatoms and radiolarians in highly productive surface waters. Because opal easily dissolves 


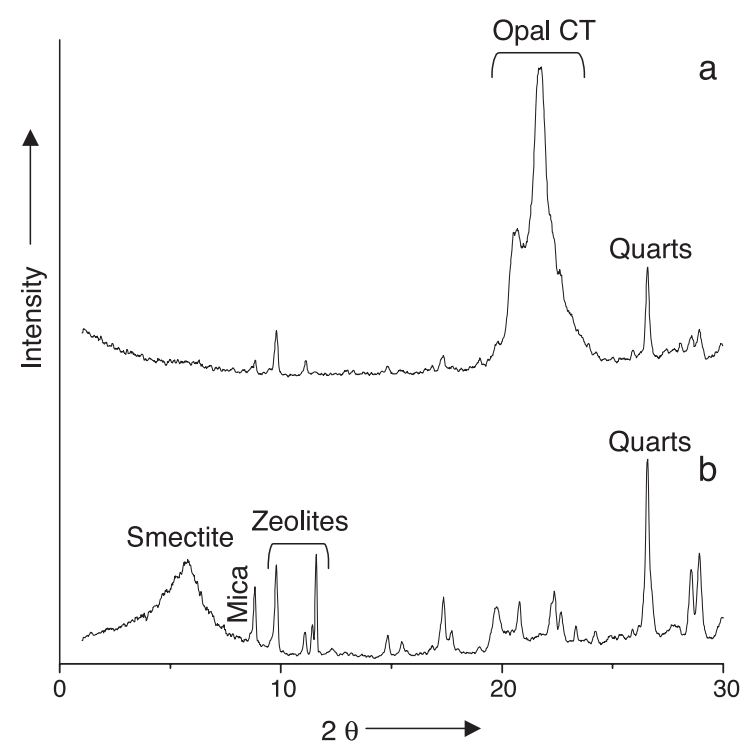

Fig. 9. Typical XRD patterns of the centre of the black claystone interval (1130.43 mbsf [a]) and the underlying green claystone interval (1130.56 mbsf [b]) of cycle 2 at DSDP Site 603B. The patterns have been smoothed by a two-point moving average.

upon sedimentation, special conditions (a high sedimentation rate and a high opal flux) are needed for its preservation. Consequently, the presence of opal indicates (but the absence of opal does not exclude) high primary productivity. Opal CT is abundant and even strongly dominates the mineralogical composition of some of the investigated samples from the center of the black claystone intervals of cycles -2 and 2.

An increase in productivity could result from changes in either growth rate or average cell size (i.e., carbon content per cell) of the phytoplanktic community. The degree of photosynthetic carbon fractionation $\left(\varepsilon_{\mathrm{p}}\right)$ for marine phytoplankton shows a strong negative correlation with both growth rate and cell size [55-59]. Therefore, an increase in productivity should be reflected in $\delta^{13} \mathrm{C}$ values of phytoplankton-derived organic matter. In accordance with this, variations in $\delta^{13} \mathrm{C}$ values for $\mathrm{OC}$ have been attributed to changes in $\varepsilon_{\mathrm{p}}$ values, resulting from changes in productivity $[60,61] . \delta^{13} \mathrm{C}$ values for inorganic carbon, which are needed to calculate $\varepsilon_{\mathrm{p}}$ values, could not directly be determined due to absence of carbonate carbon at DSDP Site 603B. Assuming that there was no significant change in the $\delta^{13} \mathrm{C}$ values for dissolved inorganic carbon during the deposition of cycle 2 , the increase in $\delta{ }^{13} \mathrm{C}$ values for S-bound phytane at Site 603B (Fig. 8) records a $\sim 1 \%$ decrease in $\varepsilon_{\mathrm{p}}$ values. This decrease may have been larger because shoaling of the chemocline discussed previously could have introduced ${ }^{13} \mathrm{C}$-depleted recycled inorganic carbon into the photic zone. Thus, it seems likely that an increase in productivity accounts for the shift in $\delta^{13} \mathrm{C}$ values for the molecular fossils of phytoplanktic origin at Site 603B. This is entirely consistent with high opal CT levels in the black claystone interval of cycle 2 .

\subsubsection{Synthesis of redox and productivity proxies}

The cooccurrence of lamination, enrichment of redox sensitive trace metals and the presence of molecular fossils of pigments from green sulfur bacteria indicate that the northern proto-North Atlantic Ocean water column was occasionally euxinic from the bottom to at least the base of the photic zone $(<150 \mathrm{~m})$ during the deposition of the black claystones (Fig. 8). In contrast, the green claystones are bioturbated, are enriched in $\mathrm{Mn}$, do not show enrichments in redox sensitive trace metals and show biomarker distributions indicative of long oxygen exposure times, indicating more oxic water conditions. At the same time, there is evidence (e.g., abundance of biogenic silica and significant ${ }^{13} \mathrm{C}$ enrichment for OC of phytoplanktonic origin) for enhanced primary productivity during the deposition of the black claystones.

We propose that enhanced productivity of OM was an important factor in generating and sustaining euxinic conditions during the deposition of the black claystones. Enhanced primary productivity periodically overwhelmed the oxic OM remineralisation potential of the bottom waters leading to the deposition of OM-rich black claystones. A combination of overall sluggish circulation (possibly halothermal instead of thermohaline) and the tectonically isolated nature of the proto-North Atlantic (Fig. 1) likely facilitated the periodic development of anoxic water column conditions [6] [Bice, personal communication]. Because the amount of oxygen used for $\mathrm{OM}$ remineralisation exceeded the amount supplied by diffusion and deep water circulation, bottom waters became euxinic. These euxinic conditions occasion- 
ally even extended into the photic zone of the protoNorth Atlantic.

\subsection{Long-term changes as a result of the OAE2}

In sediments deposited during OAE2, the average TOC contents at both sites are significantly higher ( $\sim 5 \%)$ than in older sediments ( $\sim 1 \%$; Figs. 3, 4 and 7$)$, while average sedimentation rates at both sites remained approximately the same, indicating a large increase in OC accumulation rates during the OAE2. Assuming constant sedimentation rates throughout the investigated sections, the average $\mathrm{OC}$ accumulation rates before and during the OAE2 were determined using the TOC contents of the bulk sediments. Prior to the OAE2, the OC mass accumulation rates (OC MAR) for Sites $105\left(0.1 \mathrm{gC} \mathrm{m}^{-2}\right.$ year $\left.^{-1}\right)$ and 603B $\left(0.3 \mathrm{gC} \mathrm{m}^{-2}\right.$ year $\left.^{-1}\right)$ were significantly smaller than the 1 and $3 \mathrm{gC} \mathrm{m}^{-2}$ year $^{-1}$ determined for the same interval at DSDP Site 367 and Site S13, respectively [9]. During the OAE2, OC accumulation rates at Sites $105\left(0.4 \mathrm{gC} \mathrm{m}^{-2}\right.$ year $\left.^{-1}\right)$ and 603B $\left(1.4 \mathrm{gC} \mathrm{m}^{-2}\right.$ year ${ }^{-1}$ ) were approximately four times greater than prior to the OAE but still significantly smaller than for the same interval at Sites 367 and S13 (3 and $10 \mathrm{gC}$ $\mathrm{m}^{-2}$ year $^{-1}$, respectively). This increase in OM accumulation rates at Sites 105 and 603B is accompanied by a substantial increase in HI values from $<80$ $\mathrm{mg}$ hydrocarbons/g TOC before to $\sim 270 \mathrm{mg}$ hydrocarbons/g TOC during the OAE2 [11]. However, these values are still significantly lower than the HI values for the OAE2 interval at Sites S13 and 367 (600-700 $\mathrm{mg}$ hydrocarbons/g TOC) $[23,62]$, indicating that the sedimentary $\mathrm{OM}$ in the northern proto-North Atlantic is more refractory than in the southern part. The sediments from Site 603B have a significantly lower abundance of redox sensitive trace metals and molecular fossils of green sulfur bacteria than Site 367 [9], indicating that the more refractory nature of $\mathrm{OM}$ resulted from more oxic conditions in the northern part of the proto-North Atlantic during the OAE2. Previously, we attributed the significant increase in marine $\mathrm{OC}$ accumulation rates in the southern part of the proto-North Atlantic (Sites S13, 144 and 367 ) to an increase in primary productivity [9]. As was pointed out by Schlanger et al. [63]; 'the widespread distribution of anoxic sediments deposited synchronously during such a short-lived event indi- cates that such sediments are not simply the product of coincidental local climatic or basinal water mass characteristics'. Therefore, it is tempting to attribute the increase in $\mathrm{OM}$ accumulation rates in the northern part of the proto-North Atlantic (Sites 105 and 603B) also to an increase in primary productivity. At the same time, average $\mathrm{Mo} / \mathrm{Al}$ (0 to 3), $\mathrm{Ni} / \mathrm{Al}$ (12 to 46 ), $\mathrm{V} / \mathrm{Al}$ (15 to 94 ) and $\mathrm{Zn} / \mathrm{Al}$ (22 to 36 ) ratios as well as the average concentration of isorenieratane (10 to 68 ng/g sediment) are all substantially enhanced, indicating more anoxic conditions during OAE2. This is in good agreement with the strong reduction in the thickness of the green claystones at both Sites 105 and 603B during the OAE2. Interestingly, the relative contributions of metals of terrestrial origin like $\mathrm{Al}$ (8.7\% to $5.7 \%$ ), $\mathrm{Ti}(0.46 \%$ to $0.32 \%)$ and $\mathrm{Zr}$ ( 84 to 61 $\mathrm{ppm})$ are all significantly reduced in the OAE2 interval relative to the underlying sediments, which could indicate an enhanced dilution by biogenic opal during the OAE2. If so, this would also indicate enhanced primary productivity. Additional data are needed to clarify this issue.

In any case, the periodic increase in productivity seems to have been more pronounced at Site 603B than at Site 105, resulting in significantly higher OM accumulation rates at the former site during the deposition of the black claystones. Lower accumulation rates of biogenic components like opal and $\mathrm{OM}$ during deposition of the black claystones may also have led to lower sedimentation rates at Site 105 . However, at both sites, the most OC-rich black claystones as well as the thinnest green claystones occur during phase $\mathrm{B}$ of the isotope excursion (i.e., plateau with maximum $\delta^{13} \mathrm{C}$ values, Figs. 3 and 4). These long-term trends most likely resulted from global environmental changes that occurred during the OAE2 possibly related to the formation of a deep water connection between North and South Atlantic basins [9].

\section{Conclusions}

(1) The high amplitude, short-term cyclic variations in TOC content and HI values of the $\mathrm{C} / \mathrm{T}$ interval at DSDP Sites 105 and 603B most likely resulted from precession-controlled changes in productivity. 
(2) Periodically increased primary productivity led to euxinic conditions in the water column of the northwestern proto-North Atlantic.

(3) These anoxic conditions, which sometimes extended to at least the base of the photic zone $(<150 \mathrm{~m})$, led to enhanced preservation of marine OM resulting in the deposition of OMrich black claystones.

(4) The trends at Sites 105 and 603B of continually increasing TOC contents and HI values of the black claystones up-section most likely resulted from both enhanced preservation due to increased anoxia and increased production of marine $\mathrm{OM}$ as a response to the environmental changes during the OAE2.

\section{Acknowledgements}

We thank M. Böttcher, H. Kinkel, S. van der Gaast, J. Köster, R. Kloosterhuis, P. Slootweg, M. Dekker, M. Baas and W. Pool for analytical assistance; the Ocean Drilling Program for providing the samples; and J. Rullkötter of the ICBM in Oldenburg for providing facilities for $\delta^{13} \mathrm{C}$ measurements. The investigations were supported by the Research Council for Earth and Lifesciences (ALW) with financial aid from the Netherlands Organization for Scientific Research (NWO) Max-Planck-Gesellschaft (MPG) and the EC Human Potential Program Research Training Networks Activity.

\section{Appendix A}

Supplementary data associated with this article can be found, in the online version, at doi:10.1016/ j.eps1.2004.09.037.

\section{References}

[1] S.O. Schlanger, H.C. Jenkyns, Cretaceous oceanic anoxic events: causes and consequences, Geol. Mijnb. 55 (1976) $179-184$.

[2] M.A. Arthur, W.A. Dean, L.M. Pratt, Geochemical and climatic effects of increased marine organic carbon burial at the Cenomanian/Turonian boundary, Nature 335 (1988) 714-717.
[3] T.J. Bralower, H.R. Thierstein, Organic carbon and metal accumulation rates in Holocene and mid-Cretaceous sediments: palaeoceanographic significance, Geol. Soc. London Spec. Publ. 26 (1987) 345-369.

[4] H.B. Zimmerman, A. Boersma, F.W. McCoy, Carbonaceous sediments and palaeoenvironment of the Cretaceous South Atlantic Ocean, Geol. Soc. London Spec. Publ. 26 (1987) 271-286.

[5] P.C. De Graciansky, G. Deroo, J.P. Herbin, L. Montadert, C. Müller, A. Schaaf, J. Sigal, Ocean-wide stagnation episode in the Late Cretaceous, Nature 308 (1984) 346-349.

[6] C.J. Poulsen, E.J. Barron, M.A. Arthur, W.H. Peterson, Response of mid-Cretaceous global circulation to tectonic and $\mathrm{CO}_{2}$ forcings, Paleoceanography 16 (2001) 576-592.

[7] C.P. Summerhayes, Organic-rich Cretaceous sediments from the North Atlantic, Geol. Soc. Spec. Publ. 26 (1987) 301-316.

[8] J.S. Sinninghe Damsté, J. Köster, A euxinic southern North Atlantic Ocean during the Cenomanian/Turonian oceanic anoxic event, Earth Planet. Sci. Lett. 158 (1998) 165-173.

[9] M.M.M. Kuypers, R.D. Pancost, I.A. Nijenhuis, J.S. Sinninghe Damsté, Enhanced productivity led to increased organic carbon burial in the euxinic North Atlantic basin during the late Cenomanian oceanic anoxic event, Paleoceanography 17 (2002) DOI:10.1029/2000Pa000569.

[10] P.C. De Graciansky, E. Brosse, G. Deroo, J.P. Herbin, L. Montadert, C. Müller, J. Sigal, A. Schaaf, Organic-rich sediments and palaeoenvironmental reconstructions of the Cretaceous North Atlantic, in: J. Brooks, A.J. Fleet (Eds.), Marine Petroleum Source Rocks, Geol. Soc. London Spec. Publ. 26 (1987) 317-344.

[11] J.P. Herbin, E. Masure, J. Roucaché, Cretaceous formations from the lower continental rise off Cape Hatteras: organic geochemistry, dinoflagelate cysts, and the Cenomanian/Turonian boundary event at Sites 603 (Leg 93) and 105 (Leg 11), Init. Rep. Deep Sea Drill. Proj. 93 (1987) 1139-1160.

[12] L. Lourens, F.J. Hilgen, W.J. Zachariase, A.A.M. Van Hoof, A. Antonarakou, C. Vergnaud-Grazzini, Evaluation of the Pliocene to early Pleistocene astronomical time scale, Palaeoceanography 11 (1996) 391-413.

[13] P. Hofmann, T. Wagner, B. Beckmann, Millennial- to centennial-scale record of African climate variability and organic carbon accumulation in the Coniacian-Santonian eastern tropical Atlantic (Ocean Drilling Program Site 959, off Ivory Coast and Ghana), Geology 31 (2003) 135-138.

[14] T. Wagner, J.S.S. Damste, P. Hofmann, B. Beckmann, Euxinia and primary production in Late Cretaceous eastern equatorial Atlantic surface waters fostered orbitally driven formation of marine black shales, Paleoceanography 19 (2004) DOI:10.1029/2003PA000898.

[15] R.A. Kühnel, S.J. van der Gaast, Advances in X-ray Analysis, Plenum Press, New York, 1993, pp. 439-449.

[16] D.H. Roberts, J. Lehar, J.W. Dreher, Time series analysis with CLEAN: Part I. Deviation of a spectrum, Aston. J. 93 (1987) 968-989.

[17] R.B. Blackman, J.W. Tukey, The Measurements of Power Spectra from the Point of View of Communication Engineering, Dover Publications, New York, 1958, 190 pp. 
[18] D. Heslop, M.J. Dekkers, Spectral analysis of unevenly spaced climatic time series using CLEAN: signal recovery and derivation of significance levels using a Monte Carlo simulation, Phys. Earth Planet. Inter. 130 (2002) 103-116.

[19] D. Paillard, L. Labeyrie, P. Yiou, Macintosh program performs time-series analysis, EOS Trans. AGU 77 (1996) 379.

[20] J. Thurow, Cretaceous radiolarians of the North Atlantic Ocean: ODP Leg 103 (Sites 638, 640, and 641) and DSDP Legs 93 (Site 603) and 47B (Site 398), Proc. Ocean Drill. Prog., Sci. Results 103 (1988) 379-418.

[21] P.Y. Chénet, J. Francheteau, Bathymetric reconstruction method: application to the central Atlantic Basin between $10^{\circ} \mathrm{N}$ and $40^{\circ} \mathrm{N}$, Init. Rep. Deep Sea Drill. Proj. 51, 52, 53 (1979) $1501-1514$.

[22] S. Kolonic, T. Wagner, A. Foster, J.S. Sinninghe Damsté, B. Walsworth-Bell, E. Erba, S. Turgeon, H.-J. Brumsack, H. Tsikos, Black shale deposition on the NW African Shelf during the Cenomanian/Turonian Oceanic Anoxic event: climate coupling and global organic carbon burial, Paleoceanography (2004) (in press).

[23] W. Kuhnt, J.P. Herbin, J.W. Thurow, J. Wiedmann, Distribution of Cenomanian-Turonian organic facies in the western Mediterranean and along the Adjacent Atlantic Margin, 30 (1990) 133-160.

[24] A.S. Gale, H.C. Jenkyns, W.J. Kennedy, R.M. Corfield, Chemostratigraphy versus biostratigraphy: data from around the Cenomanian-Turonian boundary, J. Geol. Soc. (London) 150 (1993) 29-32.

[25] H. Tsikos, H.C. Jenkyns, B. Walsworth-Bell, M.R. Petrizzo, A. Forster, S. Kolonic, E. Erba, I.P. Silva, M. Baas, T. Wagner, J.S.S. Damste, Carbon-isotope stratigraphy recorded by the Cenomanian-Turonian Oceanic Anoxic event: correlation and implications based on three key localities, J. Geol. Soc. 161 (2004) 711-719.

[26] J.M. Hayes, B.N. Popp, R. Takigiku, M.W. Johnson, An isotopic study of biochemical relationships between carbonates and organic carbon in the Greenhorn formation, Geochim. Cosmochim. Acta 53 (1989) 2961-2972.

[27] K.H. Freeman, J.M. Hayes, Fractionation of carbon isotopes by phytoplankton and estimates of ancient $\mathrm{CO}_{2}$ levels, Glob. Biochem. Cycles 6 (1992) 185-198.

[28] J.S. Sinninghe Damsté, M.D. Kok, J. Köster, S. Schouten, Sulfurized carbohydrates: an important sedimentary sink for organic carbon? Earth Planet. Sci. Lett. 164 (1998) 7-13.

[29] M.E.L. Kohnen, S. Schouten, J.S. Sinninghe Damsté, J.W. De Leeuw, D.A. Merritt, J.M. Hayes, Recognition of paleobiochemicals by a combined molecular sulfur and isotope geochemical approach, Science 256 (1992) 358-362.

[30] S. Schouten, W.C.M. Klein Breteler, P. Blokker, N. Schogt, W.I.C. Rijpstra, K. Grice, M. Baas, J.S. Sinninghe Damsté, Biosynthetic effects on the stable carbon isotopic composition of algal lipids: implications for deciphering the carbon isotopic biomarker record, Geochim. Cosmochim. Acta 62 (1998) $1397-1406$.

[31] J.K. Volkman, A review of sterol markers for marine and terrigenous organic matter, Org. Geochem. 9 (1986) 83-99.
[32] L.J. Goad, Sterol biosynthesis and metabolism in marine invertebrates, Pure Appl. Chem. 51 (1981) 837-852.

[33] M. Rohmer, P. Bisseret, S. Neunlist, The hopanoids, prokaryotic triterpenoids and precursors of ubiquitous molecular fossils, in: J.M. Moldowan, P. Albrecht, R.P. Philp (Eds.), Biological Markers in Sediments and Petroleum, Prentice Hall, New Jersey, 1992, pp. 1-17.

[34] G. Eglinton, R.J. Hamilton, Leaf epicuticular waxes, Science 156 (1967) $1322-1335$.

[35] M.D. Kok, W.I.C. Rijpstra, L. Robertson, J.K. Volkman, J.S. Sinninghe Damsté, Early steroid sulfurisation in surface sediments of a permanently stratified lake (Ace Lake, Antarctica), Geochim. Cosmochim. Acta 64 (2000) 1425-1436.

[36] R.E. Summons, L.L. Jahnke, J.M. Hope, G.A. Logan, 2Methylhopanoids as biomarkers for cyanobacterial oxygenic photosynthesis, Nature 400 (1999) 554-557.

[37] M.M.M. Kuypers, Y. van Breugel, S. Schouten, E. Erba, J.S. Sinninghe Damsté, $\mathrm{N}_{2}$-fixing cyanobacteria fuelled Cretaceous oceanic anoxic events, Geology 32 (2004) 853-856.

[38] S.R. Larter, B. Horsfield, Determination of structural components of kerogens by the use of analytical pyrolysis methods, in: M.H. Engel, S.A. Macko (Eds.), Organic Geochemistry; Principles and Applications, Plenum Press, New York, 1993, pp. 271-287.

[39] T.I. Eglinton, J.S. Sinninghe Damsté, M.E.L. Kohnen, J.W. De Leeuw, Rapid estimation of the organic sulphur content of kerogens, coals and asphaltenes by pyrolysis-gas chromatography, Fuel 69 (1990) 1394-1404.

[40] M.A. Arthur, W.E. Dean, G.E. Claypool, Anomalous ${ }^{13}$ C enrichment in modern marine organic carbon, Nature 315 (1985) 216-218.

[41] F.J. Hilgen, Astronomical calibration of gauss to Matuyama sapropels in the Mediterranean and implication for the geomagnetic polarity time scale, Earth Planet. Sci. Lett. 104 (1991) 226-244.

[42] A. Berger, M.F. Loutre, J. Laskar, Stability of the astronomical frequencies over the earth's history for paleoclimate studies, Science 255 (1992) 560-566.

[43] W. Kuhnt, Abyssal recolonization by benthic foraminifara after the Cenomanian/Turonian boundary anoxic event in the North Atlantic, Mar. Micropaleontol. 19 (1992) 257-274.

[44] I.A. Nijenhuis, G.J. De Lange, Geochemical constraints on Pliocene sapropel formation in the eastern Mediterranean, Mar. Geol. 163 (2000) 41-63.

[45] J. Thomson, N.C. Higgs, T.R.S. Wilson, I.W. Croudace, G.J. de Lange, P.J.M. van Santvoort, Redistribution and geochemical behaviour of redox-sensitive elements around $\mathrm{S} 1$, the most recent eastern Mediterranean sapropel, Geochim. Cosmochim. Acta 59 (1995) 3487-3501.

[46] S.E. Calvert, T.F. Pedersen, Geochemistry of Pleistocene sapropels and associated sediments from the eastern Mediterranean, Mar. Geol. 113 (1993) 67-88.

[47] M.A. Arthur, H.C. Jenkyns, H.J. Brumsack, S.O. Schlanger, Stratigraphy, geochemistry, and paleoceanography of organic carbon-rich Cretaceous sequences, Cretac. Resour. Events Rhythms (1990) 75-119. 
[48] M.J.L. Hoefs, W.I.C. Rijpstra, J.S. Sinninghe Damsté, The influence of oxic degradation on the sedimentary biomarker record: I. Evidence from Madeira abyssal plain turbidites, Geochim. Cosmochim. Acta 66 (2002) 2719-2735.

[49] J.S. Sinninghe Damsté, W.I.C. Rijpstra, G.-J. Reichart, The influence of oxic degradation on the sedimentary biomarker record: II. Evidence from Arabian Sea sediments, Geochim. Cosmochim. Acta 66 (2002) 2737-2754.

[50] J.S. Sinninghe Damsté, M.M.M. Kuypers, S. Schouten, S. Schulte, J. Rullkötter, The lycopane/C-31 $n$-alkane ratio as a proxy to assess paleoxicity during sediment deposition, Earth Planet. Sci. Lett. 209 (2003) 215-226.

[51] D.J. Repeta, D.J. Simpson, B.B. Jørgensen, H.W. Jannasch, Evidence for anoxygenic photosynthesis from the distribution of bacteriochlorophylls in the Black Sea, Nature 342 (1989) $69-72$.

[52] J.S. Sinninghe Damsté, S.G. Wakeham, M.E.L. Kohnen, J.M. Hayes, J.W. De Leeuw, A 6000-year sedimentary molecular record of chemocline excursions in the Black Sea, Nature 362 (1993) 827-829.

[53] D.J. Repeta, A high resolution historical record of Holocene anoxygenic primary production in the Black Sea, Geochim. Cosmochim. Acta 57 (1993) 4337-4342.

[54] H. van Gemerden, J. Mas, Ecology of phototrophic sulfur bacteria, in: R.E. Blankenship, M.T. Madigan, C.E. Bauer (Eds.), Anoxygenic Photosynthetic Bacteria, Kluwer Academic Publishers, Dordrecht, 1995, pp. 49-85.

[55] E.A. Laws, B.N. Popp, R.R. Bidigare, M.C. Kennicutt, S.A. Macko, Dependence of phytoplankton carbon isotopic composition on growth rate and $\left(\mathrm{CO}_{2}\right)_{\mathrm{aq}}$ : theoretical considerations and experimental results, Geochim. Cosmochim. Acta 59 (1995) 1131-1138.

[56] R.D. Pancost, K.H. Freeman, S.G. Wakeham, C.Y. Robertson, Controls on carbon isotope fractionation by diatoms in the Peru upwelling region, Geochim. Cosmochim. Acta 61 (1997) $4983-4991$
[57] B.N. Popp, E.A. Laws, R.R. Bridigare, J.E. Dore, K.L. Hanson, S.G. Wakeham, Effect of phytoplankton cell geometry on carbon isotopic fractionation, Geochim. Cosmochim. Acta 62 (1998) 69-77.

[58] R.R. Bidigare, K.L. Hanson, K.O. Buesseler, S.G. Wakeham, K.F. Freeman, R.D. Pancost, F.J. Millero, P.A. Steinberg, B.N. Popp, M. Latasa, M.R. Landry, E.A. Laws, Iron-stimulated changes in $\delta{ }^{13} \mathrm{C}$ fractionation and export by equatorial Pacific phytoplankton: toward a paleo growth rate proxy, Paleoceanography 14 (1999) 589-595.

[59] S. Burkhardt, U. Riebesell, I. Zondervan, Effects of growth rate, $\mathrm{CO}_{2}$ concentration, and cell size on the stable carbon isotope fractionation in marine phytoplankton, Geochim. Cosmochim. Acta 63 (1999) 3729-3741.

[60] R.V. Krishnamurthy, P.A. Meyers, N.A. Lovan, Isotopic evidence of sea-surface freshening, enhanced productivity, and improved organic matter preservation during sapropel deposition in the Tyrrhenian Sea, Geology 28 (2000) $263-266$.

[61] A.E. Murphy, B.B. Sageman, D. Hollander, Eutrophication by decoupling of the marine biogeochemical cycles of $\mathrm{C}, \mathrm{N}$, and P: a mechanism for the Late Devonian mass extinction, Geology 28 (2000) 427-430.

[62] J.P. Herbin, L. Montadert, C. Müller, R. Gomez, J.W. Thurow, J. Wiedmann, Organic-rich sedimentation at the Cenomanian-Turonian boundary in oceanic and coastal basins in the North Atlantic and Tethys, Geol. Soc. London Spec. Publ. 21 (1986) 389-422.

[63] S.O. Schlanger, M.A. Arthur, H.C. Jenkyns, P.A. Scholle, The Cenomanian-Turonian oceanic anoxic event: I. Stratigraphy and distribution of organic carbon-rich beds and the marine $\delta{ }^{13} \mathrm{C}$ excursion, Geol. Soc. Spec. Publ. 26 (1987) 371-399.

[64] C.R. Scotese, J. Golonka, Paleogeographic Atlas, University of Texas, Arlington, 1992. 